\title{
Educational and Behavioral Disparities among Kindergarten Children and their Peers Who did not enroll in it from the Point of View of the First Grade Teachers in the Light of Some Variables
}

\author{
Mohammed Ali Bani Khalid: Isra University, Jordan.
}

\begin{abstract}
This study aims to know the educational and behavioral differences between kindergarten children and their friends who did not enrolled in kindergarten from point of view of first grade teachers, the total sample of the study consist of 58 first grade teachers. to achieve the goals of the study the analytical descriptive approach has been used, tool of the study has been developed by the researcher consisting 43 items distributed into four areas were checked by specialist professors. Results indicated that there are educational and behavioral differences in favor of the students who attend the kindergarten, which is presents the important of kindergarten stage.
\end{abstract}

Key words: Differences, Kindergarten, Educational, Behavioral.

\section{Introduction}

Education occupies a distinguished position within its many and important institutions, and its advantage lies in its being the basis and the reason for the continuity of the nation's civilization and its progress. Primary education and the first grade, in particular, constitutes the first building block upon which construction is based. So educators are scientists and teachers who pay the first grade their interest, and work hard to develop teaching methods to suit students at the age of six years to learn the first letters and words. Within these considerations, the first grade intervene on affecting one way or another in the educational situation. One of these variables is the problem of the presence of students coming from the kindergarten who possess a certain amount of knowledge, skills and appropriate behaviors over the two years spent by the child in the kindergarten. In comparison with a student who starts learning directly from the house and does not have the same education or knowledge as the kindergarten child.

It is the responsibility of the educational system to prepare the learners scientifically and educationally to meet the changing demands of life and to meet the challenges facing them in various fields. This preparation requires the design of educational programs capable of providing them with basic science skills, research and exploration skills and different thinking skills, Confronting the problems they face in a scientific and creative way. Most interest in modern scientific education has become focused on the possession of learners of these skills through which they are equipped with facts and knowledge and concepts and positive attitudes towards different sciences. There is no doubt that kindergartens, which are the first educational institution under 6 years of age, receive children from the age of 3 years entrusted with the development of thinking skills and the provision of scientific knowledge for children. This stage is of crucial

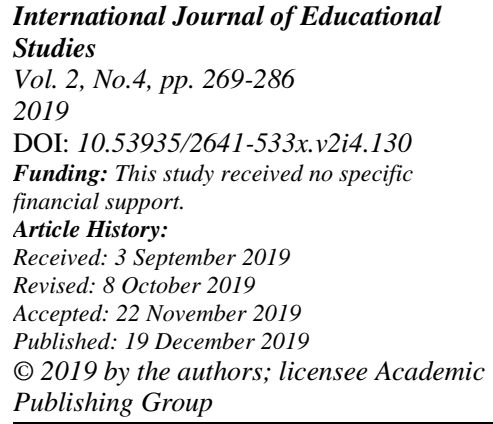


importance in shaping the personality of children in different aspects, (The Arab Council for Childhood and Development, 2001).

Kindergartens are educational and social institutions that seek to properly qualify the child to attend the primary stage so that the child does not feel the sudden move from home to school, giving him full freedom to exercise his activities and to discover his abilities, tendencies and possibilities, thus Kindergartens seek to help the child to acquire new skills and experiences, Children at this stage are between the ages of 3 and 6 .

Children at this stage need constant encouragement from the teachers of Kindergarten to develop their love of teamwork, to instill a spirit of cooperation, positive participation, self-reliance and confidence, and to acquire a lot of language, social skills and sound attitudes toward the educational process (Badran, 2002).

With the increase of family's responsibility in education, especially the family, which lack the conditions that help to raise the child correctly, keeping in mind that the factors vary from one family to another and from one community to another, so there is an urgent need to establish kindergartens, to help the family to raise their children, which shows the important role of kindergarten in building a child's personality and helping in its overall development (Faraj, 1991).

The need for kindergartens has become urgent, especially in recent years because of the economic situations and the increase in the number of working women. Kindergartens also help to provide full care for the child. It is considered a bridge to move the child from the family atmosphere to the primary school environment, after meeting his social and psychological needs, through targeted and comprehensive activities, games and programs provided by the kindergarten leading to satisfy the basic needs of children.

Mellou (1994) noted that peer experience enriches the child's behavioral skills and influences social interaction with his or her parents and other adults that is a key issue for their natural growth. He also emphasized that the social interaction of the child is influenced by the playmate and the degree of peer knowledge. Interaction with a familiar partner is more sophisticated and more frequent than interacting with a new or unfamiliar peer.

Consequently, teacher, student and even school administration face a challenge to overcome this dilemma. There are many discrepancies and differences between kindergarten students and their peers that require treatment and finding ways to achieve harmony and agreement between the two groups.

Plato referred to the impact of tradition and customs in society in formatting the behavior of the individual through the transfer between individuals as he explained the behavior of the human being that the general output of the various influences of society, and thus can change the behavior of the individual through educational and social bodies (Zahran, 1984)

Many studies have shown that kindergartens have a role in the development of mental, social, psychological, and collective growth aspects and the types thinking. Ratiff (1986) found that social growth in preschool affect achievement and confirmed that the proper growth of children in kindergarten affects their primary school achievement (Ratiff, 1986).

The kindergarten stage is considered a non-instructional stage, as far as what is a stage comprehensive development of the child's senses, abilities and attitudes. The main goal of kindergarten is not to acquire information, although the true value of knowledge embodies as it is a means of achieving comprehensive child development and preparing him for the primary stage. This preparation does not come about by providing the child with much information, but the importance of kindergarten as a tool for comprehensive preparation of the personality of the child mentally, emotionally, socially and physically within the limits of his potential, readiness and level of maturity (Mustafa, 2001).

\subsection{Research Problem}

The problem of the research emerges from the variance between two groups of students, one group graduated from the Kindergarten possessing a certain amount of knowledge, information, learning skills, and appropriate behaviors, while the other group comes directly from home and have never been exposed to any education. So, the teacher is expected to face the dilemma of the

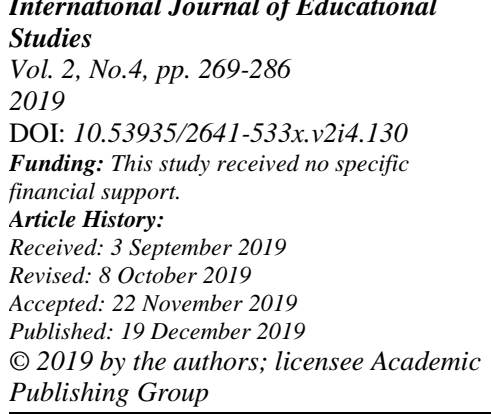


agreement between the two groups that differ in the level of their knowledge and behavior, thus posing a challenge and a problem that needs appropriate solutions and treatments.

Therefore, the research seeks to determine the dimensions of these variances in educational and behavioral aspects, and make proposals to treat them.

\subsection{The Objectives of the Research}

This research aims to reveal the educational and behavioral differences between children who graduated from kindergarten and their peers who did not enter kindergarten after they joined the first grade, from the point of view of the teachers of the first grade and its ways of treatment.

\subsection{Research Questions}

- What are the educational and behavioral differences that exist between children graduated from kindergarten and their peers who did not enter kindergarten?

- Are there statistically significant differences attributed to research variables such as (gender: male / female) (years of service: $\{1$ - 10 years), $\{11$ years and above)) and (Scientific Qualification: Bachelor/ Master or more)

\subsection{Research Limits}

Time Limits: Academic Year 2018/2019.

Spatial Limits: Primary schools in the Directorate of Education of Jerash.

Objective Limits: Educational and Behavioral Disparities among Kindergarten Children and their peers who did not attend it from the point of view of teachers of the first grade.

Human Limits: Teachers of the first grade in the Directorate of Education of Jerash.

\subsection{Research Importance}

The importance of research is as follows:

1. Theoretical Importance:

i) The importance of the detection of educational and behavioral differences of first grade students who enrolled in kindergarten and those who did not join them.

ii) The special importance of the first grade as a basis for building, and the need for this class to have a high degree of harmony and to provide a positive atmosphere for these students.

iii) The importance of proposing solutions and appropriate treatments, to overcome the dilemma of educational and behavioral differences between the two groups of students to achieve comfortable learning and education.

iv) The importance of information provided by the research enriches the educational library and encourages further studies.

2) Practical importance:

i) The present research could serve to make recommendations and proposals that would contribute to addressing the problem that it had addressed.

ii) Work on the development and improvement of kindergartens and give it more attention.

iii) Organizing joint workshops between kindergarten teachers and first grade primary teachers to exchange shared experiences and knowledge.

iv) Conduct awareness meetings for parents so that they would grasp the importance of bringing their children to kindergarten, as a very important stage before entering primary school.

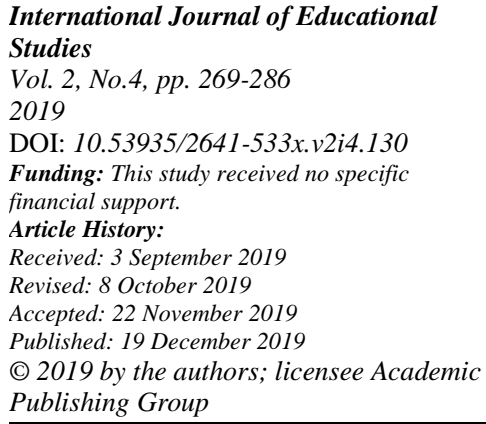

\subsection{Research Terms}

First Grade: This is the beginning of the primary stage of the educational ladder in the Hashemite Kingdom of Jordan, starting from the age of six years (Al-Ruwaili, 2011).

Procedural: It is the first class in the primary school educational ladder, which is mandatory where the child enters at the age of (6) years. 
Kindergarten: It is a stage of pre-school education, from the age of (5-6) years, in which the child enters the Kindergarten. It is equipped with a special way to suit children and their learning and to develop their mental, physical, emotional and social abilities (Abu, Sayegh, \& Al-Saadi, 2004).

Procedural: It is a non-teaching stage directly attended by the child from the age of (5-6) years, contribute to build the capacity and personality of the child in an integrated manner, which is not mandatory in the educational ladder in Jordan.

Educational: It is the total knowledge, skills and attitudes that the student has after passing through kindergarten, which can be measured by the appropriate measuring tools (Saadi, 2006).

Behavioral: These are the educational goals that are formulated in a way that describes the behavior that will be acquired by the child after passing through a specific educational experience, whether that behavior, cognitive or physical or emotional movement (Attiyah, 2006).

\section{Theoretical Framework}

The human element is one of the most important elements of creative production, and its abilities and skills are directly affected by what is received in childhood. The interest in childhood is an interest in both present and future. The first five years is one of the most important stages in a person's life. It is the conscious society that knows and appreciates the importance of childhood and pays more attention to it than any other stage. Because the experience of the first years of life in the child's life is of great importance in shaping future growth. The opportunities for human development depend heavily on attention and care provided by the society to the child, which confirms that the cultural, scientific and economic success of countries is influenced by the effectiveness of education programs, including early childhood (Guinness, 2001). Therefore, it can be said that the conflict between the developed countries is a struggle between their children's minds in order to reach a scientific and technological precedent to ensure entrepreneurship and leadership.

The task of kindergartens is to discover the child's talents and abilities, then to work on providing the appropriate educational climate for the development of abilities and talents through the exercise of various types of free and directed activity, so that he can benefit from it and use it in his next school life. Kindergartens also provide the child with certain skills that arise from his / her needs in a relaxed environment, and an appropriate environment away from oppression and fatigue (Adas, 2009).

Piaget is considered the pioneer of cognitive and behavioral theory, such as cognitive growth and development, which is part of the process of maturation in the field of general experience. Social behavior takes place in successive steps. The individual progresses according to age (Wads, 1984).

The stage of kindergarten is a critical stage in the development of various aspects of the child's mental, linguistic, physical, spiritual and social development. At this stage, personality traits are identified, patterns of behavior are established, and the child's abilities, aptitudes and concepts begin (Edwards, 2000).

The scientific knowledge acquired by the child through scientific activities have a role in the development of creative thinking skills, after many scientists have agreed that creativity is not exclusive to certain people, creativity exists in every child. Creativity appears and can be taught and developed as any skill a person learns through well-prepared programs. The greater the child's knowledge resources, the greater the ability to think creatively or to deal better with life. Therefore, it is always preferable to introduce children to kindergarten so that they learn knowledge, values and behaviors that will help them to adapt better in their later studies.

Hence, the contemporary educational systems seek to invest the mental abilities of the learners in all educational stages, starting from the stage of kindergarten through the setting educational programs that develop their various mental abilities, including creative thinking skills that can be developed in kindergarten through different activities In particular scientific activities. As says, some early creative thinking in children can be observed by holding, shaking, rotating, and

International Journal of Educational
Studies
Vol. 2 , No.4, pp. $269-286$
2019
DOI: $10.53935 / 2641-533 x . v 2 i 4.130$
Funding: This study received no specific
financial support.
Article History:
Received: 3 September 2019
Revised: 8 October 2019
Accepted: 22 November 2019
Published: 19 December 2019
() 2019 by the authors; licensee Academic
Publishing Group

Publishing Group 
manipulating things in many ways. Many children in early childhood also exhibit a great deal of creativity and self-learning.

Modern science programs no longer focus on filling the learner's mind with facts and knowledge. Rather, they emphasize that it is very important for a child to acquire different scientific, research and thinking skills through scientific activities that organize and plan to stimulate creative thinking for children. There are many scientific and technological activities that help children develop their creative thinking.

The researcher believes that Kindergarten can provide in its programs a lot of knowledge and science that make the child precede in his stored knowledge others who did not enter kindergartens. Despite, the diversity of sources of knowledge now, but in the kindergarten they are intended, purposeful, organized and supervised by effective teachers are as expected.

The child in the kindergarten stage shows and understands the skills of the following basic science processes: observation, classification, communication, measurement, estimation, prediction, and reasoning. The importance of scientific knowledge, which consists of facts, concepts, principles and theories, is that it enables children to understand that many sciences are empirical and therefore change with time and subdue to future change. When children use scientific skills, it helps them to create and discover more ideas and things on their own, and it helps to expand their learning through experience. Children begin with simple ideas and then these ideas combine to form new and more complex ideas. These ideas contribute to making children decision-makers, consumers of knowledge and citizens who are better able to solve their problems. The knowledge acquired by children provides them with power and responsibility to use it (Martin, Ralfuskston, Kollenwanger, Kaijirovic, \& Jack, 1998).

The child in early childhood is an active researcher of knowledge characterized by curiosity and passion for knowledge to reveal concepts, facts and phenomena that are not clear to him. Therefore, it is necessary to provide science to kindergarten children through activities that satisfy the curiosity of children to knowledge and discovery and to allow them to participate and interact through the senses, which are doors to knowledge, making it an active participant in building it. The important thing for a pre-school child is to provide him with a great deal of action and performance for what he is doing rather than the large amount of information about the thing. Learning how to get answers is more important than the answers themselves (Al-Baghdadi, 2001).

The child is born with the ability to learn, but is not born with behavioral patterns, which he learns from social life, Learning constitutes his character in such a way that he is fit for an organized life that follows certain patterns that are accepted by small groups and large groups, and by society at large, This superlative ability to learn that God has given to man transcends what is found in all other creatures. It is the basis upon which society depends to control man and his motives so that his behavior conforms to the prevailing social life.

The results of the German Corporation for Technical Cooperation GTZ show that the level of achievement

of students in primary education stage, especially in the first three grades, in mathematics and Arabic is higher than the average of achievement of students who did not attend kindergarten. The difference between the averages was statistically significant at $\alpha \leq 0.01$. Pre-school children acquire the basics of sound education within kindergarten provided that the educational program is flexible and expandable in activities suitable for the child. Therefore, educators in kindergarten emphasize that the period spent in kindergarten should be safe and reassuring because the child's growth during this period helps to acquire his exciting experiences (Salah, 2001).

Some Arab countries such as the United Arab Emirates and Saudi Arabia are also moving to make the kindergarten stage compulsory. In this regard, Sheikha Al Mulla, Director of the Center for the Development of Kindergartens in Dubai, confirmed that there is a gap between kindergarten and primary school, which led the Center to develop proposals to be submitted to the Minister of Education, in order to include the stage of kindergartens within the national document of the curriculum of the ministry as it does not include this stage, then to include of it as a mandatory stage in education as it is not at the present time, and to develop special standards for this stage by the Ministry of Education (Halawa, 2011).

Studies

Vol. 2, No.4, pp. 269-286

Funding: This study received no specific financial support.

Revised: 8 October 2019

Accepted: 22 November 2019

Published: 19 December 2019

(C) 2019 by the authors; licensee Academic Publishing Group 
Those interested in childhood studies and pedagogy agree that Kindergartens are pre-primary education but differ in their names as "Kindergarten, Nursery, Early Childhood Education or PreSchool Education." In general, these terms mean that kindergarten is "the educational place that promotes the care of children, sponsors their physical, mental and psychological development, facilitates their transition from domestic life to school education, and welcomes those children who have completed the third year of their life".

One aspect of Jordanian Ministry of Education's interest in kindergartens is the creation of sections in public schools offering free kindergarten education. Kindergartens have been introduced in nine districts. The number of kindergartens reached 51 with a total of 275 children, then the number of sections in public schools has increased to be 203 by a percentage of $72 \%$. The Ministry of Education in Jordan worked with the National Council for Family Affairs to implement the National Project for the Development of Kindergarten Education with support from the Arab Gulf Program for Supporting Development Organizations to contribute to the development of kindergartens in Jordan. People have become more interested in enrolling their children in school, also the preparation of a child to be enrolled in kindergarten has got more attention so as to at a higher level when joining the primary school than those who did not enroll in kindergartens, which could guarantees their academic superiority later (Bani, 2013).

There are many evidences highlight the importance of kindergarten as a stage, and its positive impact on the future of life for children. It has been shown that enrollment in kindergarten programs promotes children's cognitive development and prepares them for success in school. Psychologists are aware of the mental and social benefits of children from their experience in preprimary education of the age group (3-6) years.

\subsection{Previous Studies}

The study of aimed to identify the impact of kindergarten enrollment on creative thinking of children aged 6 years according to gender variable, the sample of the study comprised (172) students of the first primary grade in Baghdad, who are at the age of (6) years. The sample was divided into two equal groups. An experimental group consisted of students graduating from kindergartens who had spent two full academic years in kindergartens and a control group represented by pupils who did not have the opportunity to attend kindergartens. The activity of drawing using circles was chosen as a measuring tool, which is the third activity of the visual part of Torrance battery for creative thinking. The results of the study showed that there are statistically significant differences in creative thinking of children according to the variable of the group and in advantage of the experimental group or the graduates of kindergartens, and there are no statistically significant differences in creative thinking of children according to gender variable.

Lababneh (2011) aimed to identify the degree of achievement of the organizations of kindergarten education integrated pre-school children, the study has identified the requirements of the integrated aspects of physical education (health, motor), and the mental (cognitive, mental), and the emotional (emotional, ethics). The study sample consisted of 60 organizations of public kindergartens. The researcher has developed a questionnaire to identify the reality of Kindergarten organization for integrated education. The study concluded that the activities practiced within kindergarten organizations helps the child of the pre-school to correctly grow in the different physical, mental, and emotional growth sides.

Hassouna (1995) aimed at designing a program to equip children from (4-6) years of tradition and independence skills, and employ the abilities of the kindergarten child, invest in teaching and teach him to acquire proper social behavior and weaken negative behavior through the activities and attitudes of the program where the study was conducted on a sample of (140) kindergarten children, divided into experimental group (70) children and control group (70) children. The researcher used the Goodenough-Harris/Draw a Person Test and the social skills drawn test of (imitation and independence) prepared by the researcher and a program to acquire the skills of imitation and independence. The results showed that there are statistically significant differences between the experimental group and control group on the scale of imitation and independence for

International Journal of Educational
Studies
Vol. 2 , No.4, pp. $269-286$
2019
DOI: $10.53935 / 2641-533 x . v 2 i 4.130$
Funding: This study received no specific
financial support.
Article History:
Received: 3 September 2019
Revised: 8 October 2019
Accepted: 22 November 2019
Published: 19 December 2019
() 2019 by the authors; licensee Academic
Publishing Group
Publishing Group 
the advantage of the two experimental groups and the disappearance of differences between males and females on the scale of imitation and independence.

Aimed to explore Pre-school Education in the Hashemite Kingdom of Jordan from Curriculum, teachers' performance, Buildings' specification and facilities and its conformance with Licensing requirements and the availability of supervision and its performance level. The results have shown that the concept of curriculum is clear mainly under the concepts of reading, writing and knowing numbers. The performance of teacher was acceptable in comparison with the environmental conditions and it is found that $56 \%$ of Kindergartens have satisfied the Licensing requirements.

Al-Watari (2006) aimed to identify the impact of kindergarten enrollment on cognitive capacity development, The study sample consisted of 240 kindergarten children in Sana'a Governorate / Yemen. The researcher used Cognitive Abilities Test (CAT) of Thorndike. The results of the study showed that there were statistically significant differences between children enrolled in kindergartens and children not enrolled in preschools in cognitive abilities tests according to gender variable.

The results of the studies conducted by and have shown that the students who participate in school activities are distinguished with the ability to achieve success and academic achievement, as well as their positive attitude with their colleagues and teachers, and enjoy a spirit of leadership and social interaction, perseverance and seriousness, and they tend to be creative and active participators. Also, they have the ability to have new experiments.

The study of the identify the relationship between the kindergarten enrollment and educational achievement in the completion of the primary education up to the ninth grade, where they obtained grades from $(75 \%-95 \%)$ and the majority of students, i.e., $80 \%$ of them who entered the kindergarten enjoyed a number of other multiple intelligences.

conducted a study entitled "The contribution of the stage of kindergartens in preparing for the primary stage." The study aimed to identify the role of kindergartens in preparation for the primary stage, the researcher used two approaches, both descriptive and inferential, to collect data and the legal texts related to the subject of study. The results of the study showed the necessity of caring for children and the importance of educational role for kindergartens and that it is the educational basis for the primary stage. The study also recommended that the family should be aware of the importance of the kindergarten stage.

Mehrez (1999) aimed to demonstrate the impact of kindergartens in physical, and mental and social growth, the study sample consisted of two groups, one experimental consisted of children who did not enrolled in kindergartens. The study used a set of metrics that measure physical, mental, and social growth, and the study results showed the superiority of children who enrolled in kindergartens in the mental development over children who are not enrolled in kindergartens.

Al-Mehdar (1990) conducted a study entitled Emotional and Social Behavior among a sample of first- grade students in the city of Mecca who were enrolled in kindergartens and who did not enroll. The study aimed to identify the differences between the first grade pupils who were enrolled in kindergartens and those who did not enroll in kindergarten in the behavioral characteristics of the emotional side, and the patterns of social behavior. The researcher used the standard method and the results showed there are statistically significant differences in the behavioral characteristics of the emotional side differences between the first grade students who are enrolled in kindergarten for the first group, as well as there are statistically significant differences in the patterns of social behavior in favor of the first group.

In 2006, Manshi conducted a study entitled "Raising the child with play and its educational applications in the family and kindergartens in the light of Islamic education." The aim of the study was to identify the curriculum of Islamic education and the method of education with play in kindergartens, where the researcher used the descriptive approach and the deductive approach. The results of the study showed that the method of education by playing is one of the Islamic educational methods used that contributes to the formation of all aspects of personal physical, mental, emotional, social, and emotional.

Shibani (2001) conducted a study on the impact of kindergarten enrollment on the achievement of the students of the first three grades of primary education in Libya. The results of

International Journal of Educational
Studies
Vol. 2, No.4, pp. 269-286
2019
DOI: $10.53935 / 2641-533 x . v 2 i 4.130$
Funding: This study received no specific
financial support.
Article History:
Received: 3 September 2019
Revised: 8 October 2019
Accepted: 22 November 2019
Published: 19 December 2019
C 2019 by the authors; licensee Academic
Publishing Group
Price
Publishing Group 


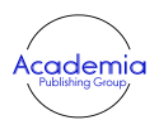

International Journal of Educational Studies

Vol. 2, No.4, pp. 269-286

2019

DOI: $10.53935 / 2641-533 x . v 2 i 4.130$

Funding: This study received no specific financial support.

Received: 3 September 2019

Revised: 8 October 2019

Accepted: 22 November 2019

Published: 19 December 2019

(C) 2019 by the authors; licensee Academic Publishing Group the study showed that there were statistically significant differences between the students who joined the kindergarten and the students who did not attend kindergarten, The study recommended the adoption of the stage of kindergarten education in Libya.

\subsection{Commenting on the Previous Studies}

A review of previous studies indicates that some studies aimed to identify the impact of kindergartens in developing the cognitive and educational capabilities of Kindergarten children such as Shibani (2001); Mehrez (1999) from which the researcher benefited to interpret the results of this study. The researcher also benefited from previous studies in the construction of the study tool and its application and procedures. This study agreed with some previous studies in the methodology and Manshi (2006). The results of this study were consistent with previous studies, which confirmed the importance of kindergartens, its role, and its impact on the development of children in an integrated, comprehensive and balanced manner. Since the kindergartens provide activities, curricula, programs and specialized games for children that make children enrolled in kindergartens distinctly educational, behavioral, emotional, social and different from their peers who did not attend kindergarten. Previous studies varied in addressing the problem of the study in different methodologies, as some used descriptive and analytical approach, other used semiexperimental approach, while some of which used the descriptive approach in contrast to that used deductive approach, as well as there are studies that used the standard method. The current study added important recommendations to make the kindergarten stage compulsory and free and a part of the educational ladder in Jordan, it also recommended the importance of improving and developing the kindergarten sector and organizing it, and to make further studies aimed at developing this stage and benefiting from international experiences in the field of kindergartens.

\subsection{Procedures and Methodology}

The researcher adopted the descriptive analytical approach to achieve the objectives of the study depending on a closed scaled questionnaire as an instrument to collect relevant data.

\subsection{Research Population}

The research population is composed of all teachers of the first grade in the public schools of Education Directorate of Jerash City who are (136) teachers (female and male) according to the statistics of the Directorate of Education of Jerash City.

\subsection{The Study Sample}

The study sample consisted of 58 teachers (female and male) who were selected using the simple random way as shown in Table 1.

Table-1. Frequencies and Percentage according to study variables.

\begin{tabular}{llll}
\hline$\#$ & Categories & Frequency & percentage \\
\hline Gender & Male & 26 & 44.8 \\
& Female & 32 & 55.2 \\
Years of Service & $1-10$ years & 35 & 60.3 \\
& 11 years & or & \\
\multirow{5}{*}{ Scientific Qualification } & more & 23 & 39.7 \\
& Bachelor & 39 & 67.2 \\
& Master & or & \\
& higher & 19 & 32.8 \\
& Total & 58 & 100.0 \\
\hline
\end{tabular}

\subsection{Research Instrument}

The researcher has adopted the following steps in order to build the instrument of the study:

- Review of theoretical literature and previous studies, despite their scarcity.

- Preparation of an open survey questionnaire consisting of three questions addressed to 
(6) male teachers and (8) female teachers.

- The researcher's experience in this field.

In light of the above, a questionnaire was prepared in its initial form consisting of (47)

\subsection{Validity of the Instrument}

In order to verify the Face validity of the instrument, the instrument was presented to (12) arbitrators with expertise and educational experience. In the light of their observations and suggestions, a number of items were deleted, modified and added so that the total number of the items of the questionnaire became (43) items.

\subsection{Reliability of the study instrument}

In order to verify the reliability of the study instrument, the test-retest was applied then reapplied two weeks later to a group of 15 teachers from outside the study sample. Then, Pearson correlation coefficient was calculated for their estimates at both times.

The reliability coefficient was also calculated using the internal consistency method according to Cronbach's alpha equation. Table 2 shows the coefficient of internal consistency according to the Cronbach's alpha equation and the regression coefficients for the domains and instrument as a whole. From the results shown in the table these values were considered acceptable for the purposes of the study.

Table-2. Test-Retest Coefficient and Cronbach's alpha coefficient.

\begin{tabular}{lccc}
\hline Field & $\begin{array}{l}\text { Test-retest } \\
\text { coefficient }\end{array}$ & $\begin{array}{l}\text { Internal } \\
\text { coefficient }\end{array}$ & consistency \\
\hline Educational differences & 0.91 & 0.78 \\
Differences in skills and activities & 0.89 & 0.76 \\
Differences in behavioral sides & 0.92 & 0.81 \\
Methods to treat educational and behavioral0.90 & 0.79 \\
differences & 0.90 & 0.91 \\
Total & & \\
\hline
\end{tabular}

After the research instrument has met the requirements of validity and consistency, a task facilitation book was obtained from the Deanship of Scientific Research at the University of Jerash and another one from the Directorate of Education of Qasabeh Jerash. The researcher distributed the copies of the questionnaire to the teachers of the first grade in their schools, due to serious follow-up, 58 valid copies of questionnaire were restored.

\subsection{Statistical tools and correction procedures}

The following statistical criteria has been adopted

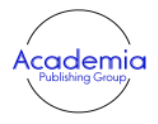

International Journal of Educational Studies

Vol. 2, No.4, pp. 269-286

2019

DOI: $10.53935 / 2641-533 x . v 2 i 4.130$

Funding: This study received no specific

financial support.

Article History:

Received: 3 September 2019

Revised: 8 October 2019

Accepted: 22 November 2019

Published: 19 December 2019

(C) 2019 by the authors; licensee Academic Publishing Group
Table-3. Convenience Criteria.

\begin{tabular}{ll}
\hline Convenience degree & Level \\
\hline 1 to $<1.67$ & Low \\
1.67 to $<2.34$ & Moderate \\
2.34 to 3 & High \\
\hline
\end{tabular}

Statistical arithmetic averages, standard deviations and three-way analysis were extracted as shown in the following statistical tables. 


\section{Results}

The results will be presented and discussed sequentially according to order of the research questions. Beginning with the (total) degree then the results of the fields, the two items that have the highest results in each field and the last item will be presented and discussed.

The first question: What are the educational and behavioral differences that exist between children graduated from kindergarten and their peers who did not enter kindergarten?

To answer this question, the arithmetical averages and standard deviations of the educational and behavioral differences between kindergarten children and their peers who did not attend kindergarten from the first grade teachers' point of view were extracted. As shown in the table below.

Table-4. Arithmetic Averages and standard deviation of the educational and behavioral differences between kindergarten children and their peers who did not attend kindergarten from the first grade teachers' point of view in descending order according to arithmetic averages.

\begin{tabular}{lllll}
\hline No. Field & $\begin{array}{l}\text { Arithmetic } \\
\text { average }\end{array}$ & S.D. & Level & Rank \\
\hline $\begin{array}{l}\text { Methods to treat educational } \\
\text { behavioral differences }\end{array}$ & and 2.67 & 0.259 & High & 4 \\
Differences in skills and activities & 2.54 & 0.237 & High & 2 \\
Differences in behavioral sides & 2.52 & 0.335 & High & 3 \\
Educational differences & 2.15 & 0.332 & Moderate & 1 \\
Total & 2.46 & 0.244 & High & \\
\hline
\end{tabular}

Table 4 illustrates that arithmetic average has ranged between (2.15-2.617). The field "Methods to treat educational and behavioral differences" has occupied the first rank with the highest mean of 2.67 since the individuals of the sample have focused their agreement upon the methods of treating the differences rather than difference itself that is an indication of the awareness of those individuals and the importance of the treatment of the differences. "Educational differences" field occupied the last rank with an arithmetic average of 2.15 as shown in the Table 4 since kindergarten does not concentrate on educational sides in comparison with behavioral and social sides. The total degree of the question as a whole has an arithmetic average of 2.46 that is of high level indicating that there are difference between the children who enrolled in kindergarten and their peers who did not enrolled in those institutions and there are certain methods to treat these differences.

Arithmetic averages and standard deviations of the estimates of the individuals of the sample were calculated for each field alone as presented in the following table.

Table 5 indicates that arithmetic averages ranged from 1.76-2.52, item 3 that states "Kindergarten students outperform their peers in reading and writing by three months" occupied the first rank with an arithmetic average of 2.52 with a high level this is due to the confidence of the individual of the sample of the existence of the differences so it is expected of them to have certain precautions to treat these differences according to the recommendations presented by the study. Item 1 that states "Kindergarten students will be able to read at least ten letters at the beginning of the school" occupied the second rank with an arithmetic average of 2.43 . This result supports the item that preceded it, as the kindergarten children lead their peers by knowing a number of letters, which makes them to learn earlier than their peers. Therefore, the first grade teacher ought to take this difference into consideration when teaching a mixed group, but slightly different in its level of education. While item (6) that states "Kindergarten students know how to write and read up to a hundred" held the last rank with an arithmetic average of 1.76. The result of this item is that the individuals of the sample are not sure that kindergarten children know how to read and write numbers up to 100 , which means that the differences between the students in this

International Journal of Educational
Studies
Vol. 2 , No.4, pp. $269-286$
2019
DOI: $10.53935 / 2641-533 x . v 2 i 4.130$
Funding: This study received no specific
financial support.
Article History:
Received: 3 September 2019
Revised: 8 October 2019
Accepted: 22 November 2019
Published: 19 December 2019
C) 2019 by the authors; licensee Academic
Publishing Group
Publishing Group 
side were not great, but the first grade teacher can easily handle it and is simpler in the case reading and writing difference that need more efforts from the teacher.

Table-5. Arithmetic averages and standard deviations of educational differences items descending order according to arithmetic averages.

\begin{tabular}{|c|c|c|c|c|}
\hline Rank & $\begin{array}{l}\text { Arithmetic } \\
\text { average }\end{array}$ & S.D. & Level & No. \\
\hline 1 & $\begin{array}{l}\text { Kindergarten students outperform their peers in } 2.52 \\
\text { reading and writing by three } \\
\text { months }\end{array}$ & 0.504 & High & 3 \\
\hline 2 & $\begin{array}{l}\text { Kindergarten students will be able to read at } 2.43 \\
\text { least ten letters at the beginning } \\
\text { of the school }\end{array}$ & 0.500 & High & 1 \\
\hline 3 & $\begin{array}{l}\text { Kindergarten students have the courage and } 2.34 \\
\text { fluency to speak }\end{array}$ & 0.479 & High & 10 \\
\hline 4 & $\begin{array}{l}\text { Kindergarten students know the basics of writing } 2.26 \\
\text { of many letters }\end{array}$ & 0.442 & Moderate & 2 \\
\hline 5 & $\begin{array}{l}\text { Kindergarten students memorize vocabulary and } 2.24 \\
\text { pronounce better more than } \\
\text { their peers }\end{array}$ & 0.779 & Moderate & 12 \\
\hline 6 & $\begin{array}{l}\text { Kindergarten students are able to deal with ten } 2.19 \\
\text { Arabic characters to construct } \\
\text { sentences and decompose it. }\end{array}$ & 0.712 & Moderate & 4 \\
\hline 6 & $\begin{array}{l}\text { I have difficulty integrating students who did not } 2.19 \\
\text { attend kindergarten with } \\
\text { their peers who enrolled it. }\end{array}$ & 0.576 & Moderate & 11 \\
\hline 8 & $\begin{array}{l}\text { I expect the excellence in the achievement will } 2.09 \\
\text { be for the kindergarten } \\
\text { students }\end{array}$ & 0.506 & Moderate & 8 \\
\hline 9 & $\begin{array}{l}\text { Kindergarten students read in sentence way } 2.05 \\
\text { better than the alphabet or } \\
\text { syllabus way }\end{array}$ & 0.867 & Moderate & 5 \\
\hline 10 & $\begin{array}{l}\text { Kindergarten students understand a set of words } 1.88 \\
\text { in English }\end{array}$ & 0.677 & Moderate & 7 \\
\hline 01 & $\begin{array}{l}\text { I find it easy to deal with kindergarten students } 1.88 \\
\text { compared to others }\end{array}$ & 0.677 & Moderate & 9 \\
\hline \multirow[t]{2}{*}{12} & $\begin{array}{l}\text { Kindergarten students know how to write and } 1.76 \\
\text { read up to a hundred }\end{array}$ & 0.757 & Moderate & 6 \\
\hline & Educational differences & .3320 & Moderate & \\
\hline
\end{tabular}

\section{The second field: differences in skills and activities}

Table 6 indicates that arithmetic averages ranged from 1.97-2.81, item 20 that states " Kindergarten students know that English writing starts from left to right " occupied the first rank with an arithmetic average of 2.81 with a high level this is due to the concern of the kindergarten teachers to teach the children some English skills to make the parents happy and proud that their child write in English. In general these skills make the student enrolled in kindergarten more advanced than their peers, which require from the teacher a smart treatment and giving the other students more concern and time from one to two months. Item 14 that states "Kindergarten students have the skills of team and individual play" occupied the second rank with an arithmetic average of 2.74 with a high level. Learning these skills by imitation, simulation and collective participation, can avoid the teacher of the first grade the direct intervention for teaching it because it is possible for non-kindergarten students to integrate in playing and learning because these activities are enjoyable, interesting and simple skills and games. While item (17) that states "Kindergarten

International Journal of Educational
Studies
Vol. 2 , No.4, pp. $269-286$
2019
DOI: $10.53935 / 2641-533 x . v 2 i 4.130$
Funding: This study received no specific
financial support.
Article History:
Received: 3 September 2019
Revised: 8 October 2019
Accepted: 22 November 2019
Published: 19 December 2019
○ 2019 by the authors; licensee Academic
Publishing Group


students know learning skills and sit calmly towards the teacher " held the last rank with an arithmetic average of 1.97 and moderate level. The difference between kindergarten students and their non- kindergarten peers is not broad. Because it is not easy to make the first-graders the habit of sitting in the class. Rather, the teacher needs a great effort to instill that habit of sitting quietly and being committed when teaching. Therefore, the effort directed to the two groups is converged.

Table-6. Arithmetic averages and standard deviations of differences in skills and activities items descending order according to arithmetic averages.

\begin{tabular}{|c|c|c|c|c|c|}
\hline No. & Items & $\begin{array}{c}\text { Arithmetic } \\
\text { average }\end{array}$ & S.D. & Level & Rank \\
\hline 20 & $\begin{array}{l}\text { Kindergarten students know that English } \\
\text { writing starts from } \\
\text { left to right }\end{array}$ & 2.81 & 0.395 & High & 1 \\
\hline 14 & $\begin{array}{l}\text { Kindergarten students have the skills of } \\
\text { team and individual } \\
\text { play }\end{array}$ & 2.74 & 0.442 & High & 2 \\
\hline 19 & $\begin{array}{l}\text { Kindergarten students know that Arabic } \\
\text { writing starts from } \\
\text { the right to the left }\end{array}$ & 2.72 & 0.451 & High & 3 \\
\hline 15 & $\begin{array}{l}\text { Kindergarten students carry many fun } \\
\text { games from } \\
\text { kindergarten }\end{array}$ & 2.66 & 0.479 & High & 4 \\
\hline 21 & $\begin{array}{l}\text { The kindergarten students correctly hold } \\
\text { the pen better than } \\
\text { their peers }\end{array}$ & 2.60 & 0.493 & High & 5 \\
\hline 18 & $\begin{array}{l}\text { Kindergarten students deal with their } \\
\text { books and tools with } \\
\text { more interest than their peers }\end{array}$ & 2.55 & 0.654 & High & 6 \\
\hline 13 & $\begin{array}{l}\text { Kindergarten students have good writing } \\
\text { skills on straight } \\
\text { lines }\end{array}$ & 2.45 & 0.502 & High & 7 \\
\hline 16 & $\begin{array}{l}\text { Kindergarten students respect the rules of } \\
\text { play and } \\
\text { commitment to the role }\end{array}$ & 2.34 & 0.479 & High & 8 \\
\hline \multirow[t]{2}{*}{17} & $\begin{array}{l}\text { Kindergarten students know learning skills } \\
\text { and sit calmly } \\
\text { towards the teacher }\end{array}$ & 1.97 & 0.748 & Moderate & 9 \\
\hline & Skills and activities differences & 2.54 & 0.237 & High & \\
\hline
\end{tabular}

The Third Field: the differences in behavioral sides

Table 7 indicates that arithmetic averages ranged from 2.19-2.79, item 23 that states "The kindergarten students ask permission before doing any work they want" occupied the first rank with an arithmetic average of 2.79 with a high level. This result is due to the fact that kindergarten students have already earned over one or two years a set of good behavioral habits related to discipline. Such result imposed on first-grade teachers making a double effort with nonkindergarten students to reach a level of behavior Kindergarten children, and their habits of discipline and order. Item 30 that states " I make great efforts with non-kindergarten students to teach them rules of discipline " occupied the second rank with an arithmetic average of 2.74 with a high level. This result is complementary to the first-ranked item in the field of behavioral differences, and the source of teachers' complaint of making more efforts with non-kindergarten students as she finds in the kindergarten students a set of rules of behavior, discipline and order that make her focus on teaching knowledge rather than behavior. While item (26) that states "Kindergarten students are quieter and more polite than their peers" held the last rank with an

International Journal of Educational
Studies
Vol. 2 , No.4, pp. $269-286$
2019
DOI: $10.53935 / 2641-533 x . v 2 i 4.130$
Funding: This study received no specific
financial support.
Article History:
Received: 3 September 2019
Revised: 8 October 2019
Accepted: 22 November 2019
Published: 19 December 2019
() 2019 by the authors; licensee Academic
Publishing Group
$\mid 280$ 
arithmetic average of 2.19 and moderate level. This result is due to two years of the students' stay at the kindergarten, which gives them some positive behaviors, including calm for some time, when the teacher enters the classroom and gives them a lesson. Although the result is late in rank but it makes a minor difference, the responses of the sample of the study need to reduce the behavioral differences between the two groups.

Table-7. Arithmetic averages and standard deviations of differences in behavioral aspects items descending order

\begin{tabular}{|c|c|c|c|c|c|}
\hline Rank & Items & $\begin{array}{l}\text { Arithmetic } \\
\text { average }\end{array}$ & S.D. & Level & No. \\
\hline$\overline{23}$ & $\begin{array}{l}\text { The kindergarten students ask permission } \\
\text { before doing any } \\
\text { work they want }\end{array}$ & 2.79 & 0.409 & High & 1 \\
\hline 30 & $\begin{array}{l}\text { I make great efforts with non- } \\
\text { kindergarten students to teach } \\
\text { them rules of discipline }\end{array}$ & 2.74 & 0.442 & High & 2 \\
\hline 28 & $\begin{array}{l}\text { I have difficulty in the first weeks } \\
\text { (behavioral) with students } \\
\text { who did not enter the kindergarten } \\
\text { He needed many weeks with non- }\end{array}$ & 2.72 & 0.451 & High & 3 \\
\hline 31 & $\begin{array}{l}\text { kindergarten students to ease their } \\
\text { attachment to their families and integrate } \\
\text { them } \\
\text { with their colleagues }\end{array}$ & 2.55 & 0.654 & & 4 \\
\hline 22 & $\begin{array}{l}\text { Kindergarten students are strictly } \\
\text { committed to the system } \\
\text { and better than their peers }\end{array}$ & 2.53 & 0.503 & High & 5 \\
\hline & I prefer to teach kindergarten children & & & High & \\
\hline 27 & $\begin{array}{l}\text { more than others } \\
\text { because they have the basis of } \\
\text { educational and behavioral in advance }\end{array}$ & 2.53 & 0.503 & & 5 \\
\hline 29 & $\begin{array}{l}\text { The differences between kindergarten } \\
\text { students and their } \\
\text { peers cause many behavioral problems }\end{array}$ & 2.47 & 0.655 & High & 7 \\
\hline 24 & $\begin{array}{l}\text { The kindergarten students avoid any } \\
\text { inappropriate words or } \\
\text { phrases }\end{array}$ & 2.45 & 0.654 & High & 8 \\
\hline 25 & $\begin{array}{l}\text { The kindergarten students avoid attacking } \\
\text { their peers }\end{array}$ & 2.45 & 0.654 & High & 8 \\
\hline 32 & $\begin{array}{l}\text { There are many irregularities and harmful } \\
\text { behaviors of non- } \\
\text { kindergarten students who need to be } \\
\text { tightened }\end{array}$ & 2.45 & 0.654 & High & 8 \\
\hline 33 & $\begin{array}{l}\text { I fear non-kindergarten students to play } \\
\text { with electricity, } \\
\text { tools and other harmful materials }\end{array}$ & 2.40 & 0.771 & High & 11 \\
\hline \multirow[t]{2}{*}{26} & $\begin{array}{l}\text { Kindergarten students are quieter and } \\
\text { more polite than their } \\
\text { peers }\end{array}$ & 2.19 & 0.576 & Moderate & 12 \\
\hline & Differences in behavioral aspects & 2.52 & 0.335 & High & \\
\hline
\end{tabular}

International Journal of Educational Studies

Vol. 2, No.4, pp. 269-286

2019

DOI: $10.53935 / 2641-533 x . v 2 i 4.130$

Funding: This study received no specific

financial support.

Article History:
Received: 3 September 2019

Revised: 8 October 2019

Accepted: 22 November 2019

Published: 19 December 2019

(C) 2019 by the authors; licensee Academic Publishing Group

\section{according to arithmetic averages.}


Table-8. Arithmetic averages and standard deviations of the items of methods of treating educational and behavioral differences descending order according to arithmetic average

\begin{tabular}{|c|c|c|c|c|c|}
\hline No. & Items & $\begin{array}{c}\text { Arithmetic } \\
\text { average }\end{array}$ & S.D. & Level & Rank \\
\hline 1 & $\begin{array}{l}\text { I feel the need for more experimental studies } \\
\text { in the field of kindergartens } \\
\text { to develop and treat problems }\end{array}$ & 2.91 & 0.283 & High & 43 \\
\hline 2 & $\begin{array}{l}\text { I communicate with parents of non- } \\
\text { kindergarten students to take care of } \\
\text { their children's education }\end{array}$ & 2.83 & 0.381 & High & 38 \\
\hline 3 & $\begin{array}{l}\text { I am interested in integrating Kindergarten } \\
\text { children with their peers and } \\
\text { reducing their educational and behavioral } \\
\text { differences, if any }\end{array}$ & 2.81 & 0.395 & High & 35 \\
\hline 4 & $\begin{array}{l}\text { I consult with my first class teachers to find } \\
\text { out the differences between } \\
\text { kindergarten students and read them }\end{array}$ & 2.72 & 0.451 & High & 37 \\
\hline 5 & $\begin{array}{l}\text { I would like the children's specialists to study } \\
\text { this dilemma and offer } \\
\text { solutions }\end{array}$ & 2.71 & 0.459 & High & 40 \\
\hline 6 & $\begin{array}{l}\text { I expect to reduce the proportion of non- } \\
\text { kindergarten students in the } \\
\text { coming years as kindergarten classes spread }\end{array}$ & 2.71 & 0.459 & High & 42 \\
\hline 7 & $\begin{array}{l}\text { I am trying to offer extra lessons for non- } \\
\text { kindergarten students to catch } \\
\text { up with their peers }\end{array}$ & 2.64 & 0.485 & High & 36 \\
\hline 8 & $\begin{array}{l}\text { It is estimated that less than half of the } \\
\text { students come from kindergarten, } \\
\text { especially in rural and desert areas }\end{array}$ & 2.62 & 0.489 & High & 41 \\
\hline 9 & $\begin{array}{l}\text { I focused my attention in the first few weeks } \\
\text { on the students who did not } \\
\text { enter the kindergarten behavioral and } \\
\text { educational }\end{array}$ & 2.57 & 0.652 & High & 34 \\
\hline 10 & $\begin{array}{l}\text { Some prefer to isolate kindergarten students in } \\
\text { separate classes to be the } \\
\text { first one with all of them } \\
\text { Methods of treating educational and } \\
\text { behavioral difference }\end{array}$ & 2.17 & 0.704 & Moderate & 39 \\
\hline
\end{tabular}

Table 8 indicates that arithmetic averages ranged from 2.17-2. 91, item 43 that states "I feel the need for more experimental studies in the field of kindergartens to develop and treat problems" occupied the first rank with an arithmetic average of 2.91 with a high level. This result is due to the fact that the research sample needs more field and experimental studies to address the problems facing them than the proposals proposed by the study. It is preferable that the studies should be based on the desire and consultation of the administration, teachers of kindergarten and teachers of the first grades. Item 38 that states "I communicate with parents of non-kindergarten students to take care of their children's education" occupied the second rank with an arithmetic average of 2.83 with a high level. The reason for this trend is attributed to the parents, because they do not feel that the differences cannot be handled by their own effort without the help of the family to close the gap between the two groups as soon as possible so that they can deal with the two groups in one context. While item (39) that states "Some prefer to isolate kindergarten students in separate

International Journal of Educational
Studies
Vol. 2 , No.4, pp. $269-286$
2019
DOI: $10.53935 / 2641-533 x . v 2 i 4.130$
Funding: This study received no specific
financial support.
Article History:
Received: 3 September 2019
Revised: 8 October 2019
Accepted: 22 November 2019
Published: 19 December 2019
○) 2019 by the authors; licensee Academic
Publishing Group


classes to be the first one with all of them" held the last rank with an arithmetic average of 2.17 and moderate level. The result is an evidence of the rejection of the individuals of the sample to discriminate between the students as they prefer to take the responsibility to treat the educational, behavioral and skills differences that is a moral standpoint to achieve the equality in education.

The second question: Are there statistically significant differences attributed to research variables such as (gender: male / female)?

To answer this question, the arithmetical averages and standard deviations of the educational and behavioral differences between kindergarten children and their peers who did not attend kindergarten according to gender variable. To demonstrate the statistical differences between the arithmetic averages (T-TEST) was used, as shown in Table 9 below.

Table-9. Arithmetic averages and standard deviations and T-test of the impact of gender in the educational and behavioral differences between kindergarten enrolled students and their peers who did not enrolled.

\begin{tabular}{|c|c|c|c|c|c|c|c|}
\hline & Gender & Sum & Mean & S.D. & $\mathbf{T}$ & D.o.F & Sig. \\
\hline \multirow{2}{*}{ Educational differences } & Male & 26 & 2.02 & 0.309 & & & \\
\hline & Female & 32 & 2.26 & 0.314 & -2.929 & 56 & $0.005^{*}$ \\
\hline \multirow{4}{*}{$\begin{array}{l}\text { Differences in Skills and } \\
\text { activities } \\
\text { Behavioral differences }\end{array}$} & Male & 26 & 2.47 & 0.219 & & & \\
\hline & Female & 32 & 2.59 & 0.242 & -1.893 & 56 & 0.064 \\
\hline & Male & 26 & 2.44 & 0.393 & & & \\
\hline & Female & 32 & 2.59 & 0.265 & -1.820 & 56 & 0.074 \\
\hline \multirow{4}{*}{$\begin{array}{l}\text { Methods of treating } \\
\text { educational and behavioral } \\
\text { difference } \\
\text { Total }\end{array}$} & Male & 26 & 2.59 & 0.330 & & & \\
\hline & Female & 32 & 2.73 & 0.164 & -2.091 & 56 & $0.041^{*}$ \\
\hline & Male & 26 & 2.36 & 0.289 & & & \\
\hline & Female & 32 & $\begin{array}{l}2.5 \\
3\end{array}$ & $\begin{array}{l}0.16 \\
9\end{array}$ & -2.759 & 56 & $0.008 *$ \\
\hline
\end{tabular}

Table 9 shows statistically significant differences $(\alpha \leq 0.05)$ due to the impact of gender in all fields and in the total score, except for the fields of differences in skills and activities, and behavioral differences. The differences were in favor of females in the first, fourth and total fields. Because female teachers are more intelligent and kind in dealing with all students without discrimination, and are more able and suitable to work with preschoolers and first-graders children than male teachers, and this is the reason for the previous calls for the feminization of primary education for the first six years have.

The second question: Are there statistically significant differences attributed to research variable years of service:

$\{1-10$ years $\},\{11$ years and above $\}$ ?

To answer this question, the arithmetical averages and standard deviations of the educational and behavioral differences between kindergarten children and their peers who did not attend kindergarten according to years of service variable. To demonstrate the statistical differences between the arithmetic averages (T-TEST) was used, as shown in Table 10.

Table 10 shows that there are statistically significant differences $(\alpha \leq 0.05)$ attributed to the impact of years of service in all fields and in the total score and in favor of the category of 11 years and above. Because as believed experience has been more likely to produce judgments in educational work, so attention to addressing the differences between the two categories of students at the first grade is essential for achieving an appropriate education for everyone.

The third question: Are there statistically significant differences attributed to research variable scientific qualification: \{ Bachelor \}, \{ Master or more \}?

To answer this question, the arithmetical averages and standard deviations of the educational and behavioral differences between kindergarten children and their peers who did not attend kindergarten according to scientific qualification variable. To demonstrate the statistical differences between the arithmetic averages (T-TEST) was used, as shown in table 10 below. 
Table-10. Arithmetic averages and standard deviations and T-test of the impact of years of service in the educational and behavioral differences between kindergarten enrolled students and their peers who did not enrolled.

\begin{tabular}{|c|c|c|c|c|c|c|c|}
\hline & $\begin{array}{l}\text { Years of } \\
\text { service }\end{array}$ & Sum & Mean & S.D. & $\mathbf{T}$ & D.o.F & Sig. \\
\hline Educational differences & $\begin{array}{c}1-10 \\
\text { years } \\
11 \text { years } \\
\text { and above }\end{array}$ & 35 & 2.06 & $\begin{array}{l}0.343 \\
0.262\end{array}$ & -2.776 & 56 & $0.007^{*}$ \\
\hline $\begin{array}{l}\text { Differences in Skills and } \\
\text { activities }\end{array}$ & $\begin{array}{c}1-10 \\
\text { years } \\
11 \text { years } \\
\text { and above }\end{array}$ & 35 & 2.47 & $\begin{array}{l}0.228 \\
0.220\end{array}$ & -2.730 & 56 & $0.008^{*}$ \\
\hline Behavioral differences & $\begin{array}{c}1-10 \\
\text { years } \\
11 \text { years } \\
\text { and above }\end{array}$ & 35 & 2.40 & $\begin{array}{l}0.316 \\
0.275\end{array}$ & -3.842 & 56 & $0.000^{*}$ \\
\hline $\begin{array}{l}\text { Methods of treating } \\
\text { educational and behavioral } \\
\text { difference }\end{array}$ & $\begin{array}{c}1-10 \\
\text { years } \\
11 \text { years } \\
\text { and above }\end{array}$ & 23 & 2.84 & $\begin{array}{l}0.216 \\
0.227\end{array}$ & -4.766 & 56 & $0.000^{*}$ \\
\hline Total & $\begin{array}{c}1-10 \\
\text { years } \\
11 \text { years } \\
\text { and above }\end{array}$ & 35 & 2.36 & $\begin{array}{l}0.199 \\
0.229\end{array}$ & -4.442 & 56 & $0.000 *$ \\
\hline
\end{tabular}

Table-11. Arithmetic averages and standard deviations and T-test of the impact of scientific qualification in the educational and behavioral differences between kindergarten enrolled students and their peers who did not enrolled

\begin{tabular}{|c|c|c|c|c|c|c|c|}
\hline & $\begin{array}{l}\text { scientific } \\
\text { qualification }\end{array}$ & Sum & Mean & S.D. & $\mathbf{T}$ & D.o.F & Sig. \\
\hline \multirow[t]{2}{*}{ Educational differences } & Bachelor & 39 & 2.21 & 0.331 & 1.845 & 56 & 0.070 \\
\hline & Master or more & 19 & 2.04 & 0.313 & & & \\
\hline \multicolumn{2}{|c|}{ Differences in Skills andBachelor } & 39 & 2.57 & 0.246 & 1.463 & 56 & 0.149 \\
\hline activities & Master or more & 19 & 2.47 & 0.209 & & & \\
\hline \multirow[t]{2}{*}{ Behavioral differences } & Bachelor & 39 & 2.59 & 0.314 & 2.172 & 56 & $0.034^{*}$ \\
\hline & Master or more & 19 & 2.39 & 0.346 & & & \\
\hline \multirow{2}{*}{\multicolumn{2}{|c|}{$\begin{array}{l}\text { Methods of treating Bachelor } \\
\text { educational and Master or more } \\
\text { behavioral difference }\end{array}$}} & 39 & 2.72 & 0.242 & 2.247 & 56 & $0.029^{*}$ \\
\hline & & 19 & 2.56 & 0.267 & & & \\
\hline \multirow[t]{2}{*}{ Total } & Bachelor & 39 & 2.51 & 0.236 & & & \\
\hline & Master or more & 19 & 2.35 & 0.228 & 2.425 & 56 & $0.019^{*}$ \\
\hline
\end{tabular}

International Journal of Educational
Studies
Vol. 2, No.4, pp. $269-286$
2019
DOI: $10.53935 / 2641-533 x . v 2 i 4.130$
Funding: This study received no specific
financial support.
Article History:
Received: 3 September 2019
Revised: 8 October 2019
Accepted: 22 November 2019
Published: 19 December 2019
C 2019 by the authors; licensee Academic
Publishing Group
284
Table 11 shows that there are statistically significant differences $(\alpha \leq 0.05)$ attributed to the impact of scientific qualification in all fields and in the total score except the fields: educational differences and differences in Skills and activities, in favor of Bachelor's holders. Because of the integration of long experience of bachelor's holders and their scientific qualification. The category of bachelor's holder is larger than master's or above holders so this difference could be only a coincidence.

\section{Conclusions}

From the research findings and discussions, we conclude the following: 
- There are differences in varying degrees at the total score level and at the fieldslevel, all of which show that differences exist between the two classes of first-graders enrolled in kindergarten and their peers who did not enrolled.

- The differences were not large or high, but ranged between medium and low.

- The proposals presented by the study were acceptable, but the sample would like experimental and field studies that stem directly from reality.

\section{Recommendations}

Based on the research findings and findings, we recommend the following:

- Paying attention to treat the differences between students enrolled kindergarten with their peers who did not enter the kindergarten more carefully, especially in the first three months.

- Considering some of the presented proposals to be perfored.

- Making proposals of experimental studies by kindergarten teachers and inform the kindergarten departments, and teachers of the first grade.

- Strengthening the relationship between kindergarten departments in universities and teachers of the first grades and kindergartens to overcome the problems arised.

- Organizing joint courses and workshops between the teachers of kindergartens and teachers of the first basic classes to exchange experiences and shared knowledge.

\section{Suggested future studies}

In order to complete this study, we propose the following future studies:

- Conducting (experimental) studies by separating students enrolled kindergarten for one or two months from their peers to compensate non-kindergarten students in some aspects.

- An evaluation study of the educational level of preschool children from the point of view of first grade teachers.

- A comparative follow-up study for two regiment of students, one who enrolled kindergarten and the other who did not enrolled kindergarten both reached the fourth grade.

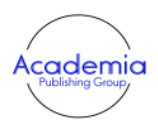

International Journal of Educational Studies

Vol. 2, No.4, pp. 269-286

2019

DOI: $10.53935 / 2641-533 x . v 2 i 4.130$

Funding: This study received no specific

financial support.

Article History:

Received: 3 September 2019

Revised: 8 October 2019

Accepted: 22 November 2019

Published: 19 December 2019

(C) 2019 by the authors; licensee Academic Publishing Group

\section{References}

Abu, T. T., Sayegh, L., \& Al-Saadi, S. (2004). The interactive national curriculum, modern foundations of preschool children. Amman: Ministry of Education.

Adas, A. R. (2009). Entrance to Kindergarten. Amman: Dar Al Fikr.

Al-Baghdadi, M. R. (2001). Creative activities for children, 1. Cairo: Arab Thought House.

Al-Mehdar, R. S. (1990). Emotional and social behavior among a sample of first-grade students in Makkah who were enrolled in Kindergarten and who did not enroll. Comparative Study, Unpublished Master Thesis, Umm Al-Qura University, Makkah.

Al-Ruwaili. (2011). Levels of thinking among first year students in the light of some variables. Unpublished Master Thesis, Irbid: Yarmouk University.

Al-Watari, A. (2006). The effect of children in the development of knowledge capacities in Sana'a. Unpublished Master Thesis, Sana'a University, Sana'a, Yemen.

Attiyah, W. F. (2006). Degree of commitment of the teachers of physical education to the foundations of the formulation of behavioral goals in the lessons of physical education in Irbid first directorate. Unpublished Master Thesis, Yarmouk University: Irbid.

Badran, S. (2002). Recent trends in pre-school child education, I 2. Cairo: Egyptian Lebanese House.

Bani, K. M. (2013). Effectiveness of the interactive national curriculum in providing Kindergarten social skills. Unpublished PhD Thesis, Red Sea University - Sudan.

Edwards, D. (2000). Empirical research education reform and current practice in Massachusetts early childhood teacher preparatory programs. Unpublished Doctorate Dissertation, University of Massachusetts.

Faraj, A. (1991). Child between family education and school, Institute of Scientific Research: Umm Al Qura University - Makkah Al Mukarramah.

Guinness, E. (2001). How we employ brain research in education. Dhahran: Dar al-Kitab al-Tarbawi for Publication and Distribution.

Halawa, R. (2011). Al Bayan Magazine, United Arab Emirates.

Hassouna, A. M. (1995). Designing a program for giving kindergarten children some social skills. PhD Thesis, Ain Shams University: Cairo.

Lababneh, A. (2011). Degree of achievement of kindergartens for integrated education of pre-school children. Unpublished Master Thesis, Balqa Applied University, Irbid College - Irbid - Jordan. 
Manshi, N. B. H. (2006). Education of the child in play and its educational applications in the family and kindergartens in the light of Islamic education. Unpublished Master Thesis, Umm Al Qura University - Makkah.

Martin, Ralfuskston, Kollenwanger, Kaijirovic, \& Jack. (1998). Education of science for all children, translated by: Zizfoon.

Mehrez, N. (1999). Factors affecting the admission of parents to their children in Kindergartens. Unpublished Master Thesis, Faculty of Education, University of Damascus, Damascus.

Mellou, E. (1994). A theoretical perspective on the relationship between dramatic play and creativity. Early Child Development and Care, 100(1), 77-92.Available at: https://doi.org/10.1080/0300443941000105.

Mustafa, F. (2001). Child and thinking skills (Vol. 1). Cairo: Arab Thought House.

Ratiff, J. (1986). Instruction in story structure Effects on preschools. Listening Comprehension The Louisiana state University P.H.D. Thesis.

Saadi, A. H. A. H. (2006). The degree of relevance of educational competencies to achieve the behavioral goals of the teachers of sports education from the perspective of their managers and supervisors. (Jenin Governorate). Unpublished Master Thesis, Yarmouk University: Irbid.

Salah, L. (2001). Socialization of our children. Paper presented at the Arab Childhood Conference and Future Prospects, South Valley University, Egypt, 28-30 October.

Shibani, M. A. A. (2001). Impact of kindergarten enrollment on the achievement of students in the first three grades of basic education in Libya. Journal of the University, 15(2).

The Arab Council for Childhood and Development. (2001). The Arab child: The Annual Statistical Report, Cairo.

Wads, W. (1984). Piayet theory of coynitive and affective development lonnaman M New York.

Zahran, H. A. S. (1984). Guidance and psychological counseling. Cairo: Book Science.

\author{
International Journal of Educational \\ Studies \\ Vol. 2, No.4, pp. 269-286 \\ 2019 \\ DOI: $10.53935 / 2641-533 x, v 2 i 4.130$ \\ Funding: This study received no specific \\ financial support. \\ Received: 3 September 2019 \\ Revised: 8 October 2019 \\ Accepted: 22 November 2019 \\ Published: 19 December 2019 \\ (C) 2019 by the authors; licensee Academic \\ Publishing Group
}

